\title{
Mutagenic activity of river water from a river near textile industrial complex in Korea
}

\section{Journal Article}

Author(s):

Kwon, Jung-Hwan; Lee, Hyun-Kul; Kwon, Jin-Wook; Kim, Kyun; Park, Eunju; Kang, Myung-Hee; Kim, Yong-Hwa

Publication date:

2008

Permanent link:

https://doi.org/10.3929/ethz-b-000081290

Rights / license:

In Copyright - Non-Commercial Use Permitted

Originally published in:

Environmental Monitoring and Assessment 142(1-3), https://doi.org/10.1007/s10661-007-9928-3 


\title{
Mutagenic activity of river water from a river near textile industrial complex in Korea
}

\author{
Jung-Hwan Kwon • Hyun-Kul Lee • \\ Jin-Wook Kwon • Kyun Kim • Eunju Park • \\ Myung-Hee Kang • Yong-Hwa Kim
}

Received: 27 February 2007 / Accepted: 28 August 2007 / Published online: 20 September 2007

(C) Springer Science + Business Media B.V. 2007

\begin{abstract}
The mutagenic activity of XAD-2 adsorbates and water extracts recovered from nine locations of the Kumho River was tested on S. typhimurium TA98 strain to identify the source of the mutagenicity. A sampling site, receiving effluents from the textile industrial complex located in Daegu City, showed extraordinarily high mutagenic activity, especially in the presence of S9 mixture, at all sampling time in both XAD-2 adsorbates and dichloromethane extracts.
\end{abstract}

\section{J.-H. Kwon $(\bowtie)$}

Department of Environmental Toxicology (UTOX),

Swiss Federal Institute of Aquatic Science

and Technology (EAWAG),

Überlandstrasse 133, P.O. Box 611,

8600 Dübendorf, Switzerland

e-mail: Jung-Hwan.Kwon@eawag.ch

H.-K. Lee

Chemon Inc.,

334 Jeilri, Yangjimyeon,

Yongin, Gyeonggido 449-826, South Korea

J.-W. Kwon

National Veterinary Research and Quarantine Service

Pusan Regional Office 620-2,

Amnam-dong, Seo-gu,

Pusan 602-030, South Korea

K. Kim

Analytical Research Center,

Korea Institute of Toxicology (KITOX),

P.O. Box 107, Yusong,

Daejeon 305-600, South Korea
This indicated the existence of the frame-shift mutagens in the Kumho River, same type of mutagens detected in previous studies by other researchers in the Nakdong River into which the Kumho River discharges. The fractionation study showed that the mutagenic chemicals in the river water are mid-polar. Furthermore, mean tail length obtained by single cell gel electrophoresis assay (Comet assay) showed consistent dosedependent DNA damage, indicating that the chemicals

\footnotetext{
Y.-H. Kim

Department of Environmental Toxicology,

Korea Institute of Toxicology (KITOX),

P.O. Box 107, Yusong,

Daejeon 305-600, South Korea

E. Park

Department of Life Science,

Kyungnam University,

449 Wolyoung-dong,

Masan 631-701, South Korea

M.-H. Kang

Department of Food and Nutrition, Hannam University,

133 Ojeong-dong, Daedeok-gu,

Daejeon 306-791, South Korea

Present address:

J.-H. Kwon

Department of Environmental Engineering,

Ajou University,

Wonchun-dong, Yeongtong-gu,

Suwon 443-749, South Korea

e-mail: jhkwon@ajou.ac.kr
} 
in the river water not only act as frame-shift mutagens but also break human lymphocytes DNA strain. Chemical identification of the mutagens should be required.

Keywords Comet assay · Genotoxicity .

Mutagenicity · River water - Source identification .

Textile industrial effluent

\section{Introduction}

During a few decades considerable attention has been paid to the anthropogenic mutagenic chemicals in surface water. The presence of mutagenic chemicals has been reported in surface water in various places of the World (Pelon et al. 1977; van Hoof and Verheyden 1981; Maruoka and Yamanaka 1982; Nakamuro et al. 1992; Vargas et al. 1993; Kusamran et al. 1994; Lee et al. 1994; Lee and Kim 1997; Park et al. 1997; Otsu et al. 1998; Kummrow et al. 2003; Umbuzeiro et al. 2004, 2005; Ohe et al. 2004; Aleem and Malik 2005).

The Nakdong River, $525 \mathrm{~km}$ long and 23,860 $\mathrm{km}^{2}$ of its watershed area, provides drinking water for about 8 million people as well as agricultural and industrial water in Korea. Recently, mutagenicity in river water from the Nakdong River was detected by the Ames Salmonella/microsome assay sensitively in TA98 strain (Lee et al. 1994; Lee and Kim 1997; Park et al. 1997; Otsu et al. 1998). The Kumho River, a tributary to the Nakdong River, into which various kinds of wastewater produced in Daegu City are discharged, supplies the main stream with approximately $10 \%$ of the volume of the river (Fig. 1). River water from the downstream of the Kumho River, near the conjunction point into the Nakdong River, showed mutagenicity (Lee et al. 1994). Effluent samples from two textile industries in Korea showed positive in the Ames mutagenicity using TA98 and TA100 with S9 (Lee et al. 1991). Even if the textile industrial complex in Daegu City was suspected as the main source of mutagenicity, the linkage between the major source of the mutagenicity in the Nakdong River and the Kumho River has not been elucidated yet. Therefore, we measured the mutagenic activity in different sections of the Kumho River water and investigated the regional contribution of the mutagenicity to the Nakdong River using the Ames test. The possible source and characteristics of the mutagenic fraction are discussed. We also confirmed the genotoxicity using Comet assay (single cell gel electrophoresis assay).
Fig. 1 The Kumho River and the Nakdong River in Korea with the locations of nine sampling sites and the sewage treatement plant (STP)

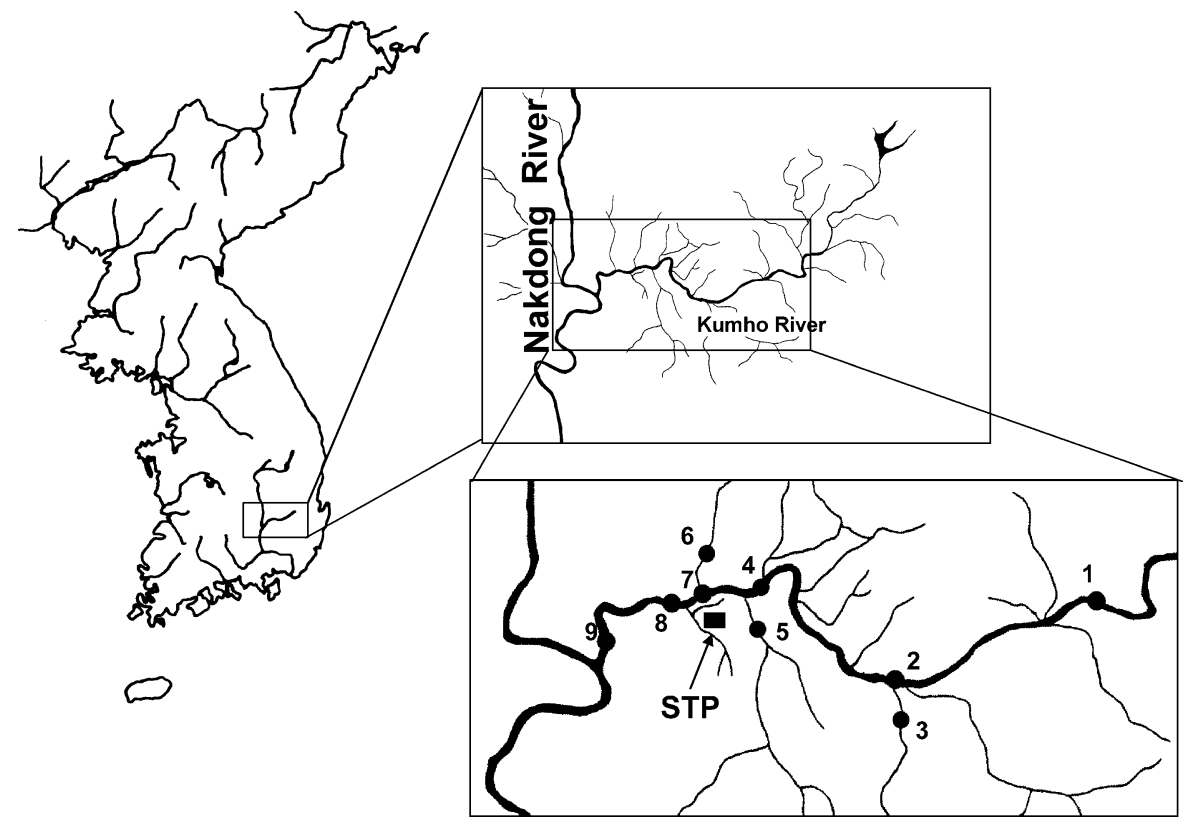




\section{Materials and methods}

Sampling and preparation for mutagenicity test

In the first screening study (May, 1999), nine locations from the Kumho River were selected to investigate the spatial difference in mutagenicity of water extracts. One-liter of all water samples were filtered and extracted with $300 \mathrm{ml}$ dichloromethane (pesticide residue analysis grade from Wako Pure Chem. Ind. Co., Ltd., Osaka, Japan) three times. The combined solvent layer was evaporated to dryness and the residue was dissolved in $0.1 \mathrm{ml}$ methanol for further analysis. After the initial screening, five locations (sites 2, 4, 7, 8, 9) were chosen for the main study (July, August, and October, 1999).

Because the dramatic differences between the site 7 and the site 8 were found in the screening study, water was also sampled at both site using XAD-2 resin (Serva Feinbiochemica GmbH and Co, Heidelberg, Germany) adsorption method (Junk 1987; LeBel et al. 1987). XAD-2 resin was used after washing consecutively with $n$-hexane, acetone, ethyl acetate, and methanol for $24 \mathrm{~h}$ in a Soxhlet extractor, increasing the polarity of the decontaminating solvents. The resin was then dried at ambient temperature for $24 \mathrm{hrs}$. A column, $2.3 \mathrm{~cm}$ diameter, was packed using $60 \mathrm{~g}$ of XAD-2 resin with glass wool filters at both ends. River water was passed through the columns at the rate of approximately $200 \mathrm{ml} / \mathrm{min}$.

\section{Solvent fractionation}

XAD-2 adsorbates were serially eluted with $300 \mathrm{ml}$ of hexane/acetone (85:15), dichloromethane, and ethyl acetate with a flow rate of $3-5 \mathrm{ml} / \mathrm{min}$ for the preliminary samples obtained in June, 1999. Methanol and ethyl acetate replaced the elution solvents for the samples of the first main study (July, 1999). Since most of mutagenic activity had been recovered in methanol extracts of XAD-2 adsorbates, XAD-2 adsorbates were eluted with $300 \mathrm{ml}$ of methanol thereafter (August, 1999 and October, 1999).

Ames mutation assay

All test samples were dissolved in $100 \mu \mathrm{l}$ of dimethylsulfoxide (DMSO, Aldrich Chem. Co. Inc., Wisconsin,
USA) and treated with direct plate-incorporation method, described by Maron and Ames (1983) using Salmonella typhimurium TA98, obtained from Molecular Toxicology Inc. (Maryland, USA) with or without S9 mixture, because previous studies indicated that the mutagenicity in river water from the Nakdong River was most sensitive in TA98 strain (Lee et al. 1994; Park et al. 1997; Otsu et al. 1998). S9 mix was prepared using Aroclor 1254-induced rat liver homogenate (S9). The S9 mixture contained $25 \mu \mathrm{l}$ of S9 in a total volume of $0.5 \mathrm{ml}$. 2-Aminoanthracene (WAKO Pure Chem. Ind., Ltd., Osaka, Japan) and 4-nitroquinoline-1-oxide (Aldrich Chem. Co. Inc., Wisconsin, USA) were used as the positive control for the test with and without S9, respectively.

\section{Comet assay}

All the chemicals used in the Comet assay were purchased from Sigma Chemicals Co. Ltd. (St. Louis, USA) except $\mathrm{H}_{2} \mathrm{O}_{2}$ (Fluka Chemie GmbH., Buchs, Switzerland). The comet assay was performed according to Singh et al. (1988) with modifications. Six-ml of fasting blood was drawn from the antecubital vein of a healthy male donor (nonsmoker aged 20 years). Fresh peripheral human lymphocytes were isolated by centrifugation with Histopaque 1077 and diluted down to a concentration of $20 \times 10^{4} / \mathrm{ml}$. The lymphocytes were then incubated with various concentrations of test samples dissolved in $100 \mu \mathrm{l}$ of DMSO, negative control (DMSO) and positive control $\left(\mathrm{H}_{2} \mathrm{O}_{2}, 25 \mu \mathrm{M}\right)$ at $4{ }^{\circ} \mathrm{C}$ for $1 \mathrm{~h}$. Fully frosted slides (Fisher scientific, Pittsburgh, USA) were covered with $0.5 \%$ normal melting agarose as the first layer, lymphocytes suspended in $75 \mu \mathrm{l}$ of $0.7 \%$ low melting agarose as second layer and $0.7 \%$ low melting agarose as third layer. After solidification at $4{ }^{\circ} \mathrm{C}$, the slides were immersed in jar containing cold lysing solution $(2.5 \mathrm{M} \mathrm{NaCl}, 100 \mathrm{mM}$ EDTA, $10 \mathrm{mM}$ Tris, $1 \%$ sodium laurylasarcosine, $\mathrm{pH} 10 ; 1 \%$ Triton X-100 and $10 \%$ DMSO were added fresh) at $4{ }^{\circ} \mathrm{C}$ for $1 \mathrm{~h}$. After lysis, the slides were placed in a horizontal electrophoresis tank (Three-Shine, Korea) filled with freshly made alkaline buffer $(300 \mathrm{mM} \mathrm{NaOH}, 10 \mathrm{mM}$ $\mathrm{Na}_{2}$ EDTA, pH 13.0) at $4^{\circ} \mathrm{C}$ for $40 \mathrm{~min}$. To electrophoresis the DNA, an electric current of $25 \mathrm{~V} / 300 \pm$ $3 \mathrm{~mA}$ was applied at $4^{\circ} \mathrm{C}$ for $20 \mathrm{~min}$. The slides were then placed in neutralization buffer ( $0.4 \mathrm{M}$ Tris, $\mathrm{pH} 7.5)$ 
and stained with ethidium bromide $(20 \mu \mathrm{l} / \mathrm{ml})$ and analyzed using a fluorescence microscope (Leica Microsystems Wetzlar GmbH., Wetzlar, Germany). Images of 100 randomly selected cells (50 cells from each of two replicate slides) were analyzed from each sample. Measurements were made by Komet 4.0 image analyser (Kinetic Imaging Ltd., UK), determining the mean tail length of the 100 cells.

Statistical analyses were performed using SPSS10.0 for Windows. All data were analyzed with one-way ANOVA with LSD test and are presented as means \pm standard error. A $P$ value less than 0.05 was considered as significant.

\section{Results}

Preliminary screening of the source of mutagenicity in the Kumho River

Table 1 shows the number of revertant colonies counted in the presence of water extracts from 9 selected sampling locations. In this screening study, dose-dependent mutagenic activity was observed at both site 8 and 9 which receive waters from the sewage treatment plant, whereas all other sampling site did not show clear differences from the control. Net revertants, obtained by subtracting control, were 61 and 21 for $143 \mathrm{ml}$ water extracts at site 8 and 9 , corresponding to approximately 450 and 150 revertants per liter, respectively.

\section{Characteristics of mutagenic chemicals}

Figure 2 shows the number of net revertants obtained using serial extract of XAD-2 adsorbates with $300 \mathrm{ml}$ of $n$-hexane/acetone (85:15), dichloromethane, and ethylacetate at site 8 sampled in June, 1999. As was observed in the preliminary screening, mutagenic activity was greater in the presence of S9 mix. Net revertants were 88, 41, 237 in $143 \mathrm{ml}$ water extracts in the presence of S9 using $n$-hexane/acetone (85:15), dichloromethane, and ethylacetate as eluting solvents.

Table 1 Reversion of TA98 strain in the presence of water extracts in May, 1999

\begin{tabular}{|c|c|c|c|c|c|}
\hline \multirow[t]{2}{*}{ Sampling site } & \multirow[t]{2}{*}{ S9 fraction ${ }^{\mathrm{a}}$} & \multirow[t]{2}{*}{ Control $^{\mathrm{b}}$} & \multicolumn{3}{|c|}{ Water extract (ml river water equivalent/plate) } \\
\hline & & & 16 & 48 & 143 \\
\hline & - & $12 \pm 3$ & & & \\
\hline & + & $21 \pm 3$ & & & \\
\hline \multirow[t]{2}{*}{1} & - & & 13 & 14 & 18 \\
\hline & + & & 18 & 22 & 27 \\
\hline \multirow[t]{2}{*}{2} & - & & 10 & 10 & 13 \\
\hline & + & & 21 & 25 & 20 \\
\hline \multirow[t]{2}{*}{3} & - & & 12 & 14 & 9 \\
\hline & + & & 16 & 24 & 18 \\
\hline \multirow[t]{2}{*}{4} & - & & 15 & 11 & 15 \\
\hline & + & & 23 & 16 & 34 \\
\hline \multirow[t]{2}{*}{5} & - & & 13 & 12 & 15 \\
\hline & + & & 22 & 17 & 27 \\
\hline \multirow[t]{2}{*}{6} & - & & 20 & 11 & 16 \\
\hline & + & & 16 & 16 & 26 \\
\hline \multirow[t]{2}{*}{7} & - & & 14 & 19 & 11 \\
\hline & + & & 22 & 18 & 23 \\
\hline \multirow[t]{2}{*}{8} & - & & 14 & 18 & 27 \\
\hline & + & & 22 & 37 & 85 \\
\hline \multirow[t]{2}{*}{9} & - & & 14 & 19 & 18 \\
\hline & + & & 20 & 26 & 42 \\
\hline
\end{tabular}

${ }^{\text {a }}$, In the absence of $\mathrm{S} 9 ;+$, in the presence of $\mathrm{S} 9$

${ }^{\mathrm{b}}$ Mean \pm standard deviation from six replicates. 
Fig. 2 Mutagenicity of the XAD-2 extracts from the Kumho River water in TA98 strain. Closed circle indicates the presence of S9 mix and open circle indicates the absence of S9 mix hexane:aceton $(85: 15)$ dichloromethane

ethylacetate

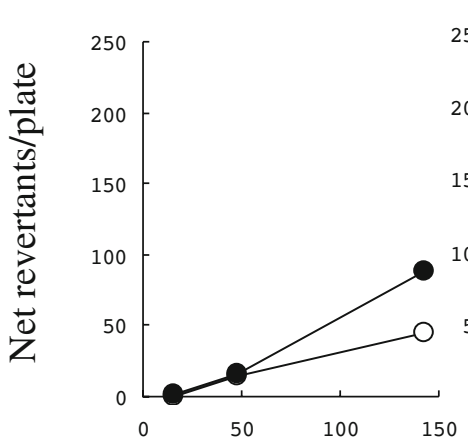

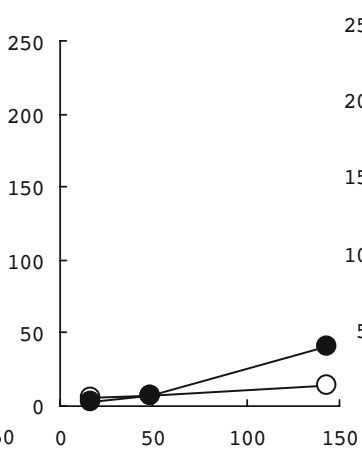

Sample (ml/plate)
Interestingly the strongest mutagenic activity was observed in the most polar ethylacetate fraction even though this fraction was eluted after the elution using the other two solvents. This indicates that major mutagens in the Kumho River are moderately polar organics and a mid-polar solvent could easily extract them from water. A follow-up experiment in July 1999 showed that most mutagenic activity at site 8 can be recovered by eluting XAD- 2 adsorbates using methanol. Ethylacetate extracts after the elution using methanol only induced less than $15 \%$ of mutagenic activity of methanol extract. Whereas the methanol fraction induced 1,180 revertants/l water, the following ethylacetate fraction only induced 160 revertants/l water.

Confirmation of mutagenic activity and genetic toxicity

To evaluate the consistency of mutagenic activity of the Kumho River, Ames mutagenicity test was conducted for the dichloromethane extracts of the water in five selected sites $(2,4,7,8$, and 9) and XAD-2 methanol extract at site 7 and site 8 in July, August, and October, 1999. Upstream sites (site 2 and 4) did not show significant differences from the negative control for all samples. Significant differences in mutagenicity between site 7 and 8 appeared at all the sampling periods (Table 2) in the presence of S9 mix regardless of extraction methods. At site 9, the mutagenic activity was alleviated from those at site 8 . Mutagenic activity recovered from liquid-liquid extraction using dichloromethane was not significantly different from XAD-2 methanol extract for samples from July 1999. However, mutagenicity was dependent on sample extraction methods for the following studies. Stronger mutagenicity was found in XAD-2 methanol extract for samples from August 1999, whereas dichloromethane extracts showed greater mutagenicity than XAD-2 extract for samples from October 1999.

The Comet assay (single cell gel electrophoresis assay) was also conducted for the XAD-2 methanol extract at site 7 and 8 to confirm the genotoxicity of the water from the Kumho River. Samples from July and October were selected. Whereas there are no differences in tail length at the samples from site 7 in both July and October sample, there is clear dosedependent DNA damage in the samples at the site 8 (Fig. 3).

\section{Discussion}

As previous studies showed that mutagenicity was detected in the water samples from the Nakdong River obtained by blue rayon suspension method (Otsu et al. 1998) and XAD-2 resin adsorption method (Lee et al. 1994; Lee and Kim 1997; Park et al. 1997), the sewage treatment plant, located in Daegu City, was thought to be the source of mutagenic chemicals. The clear difference in the number of revertants between site 7 and site 8 showed that the frame shift mutagenic chemicals are originated from sewage treatment plant that mostly treats effluents from textile industry of the city. The mutagenic index, the ratio of mutagenicity of samples to those of negative control at the sampling spot close 
Table 2 Reversion of TA98 strain in the presence of dichloromethane extracts and XAD-2 extracts at three sampling locations

\begin{tabular}{|c|c|c|c|c|c|c|c|c|c|}
\hline \multirow[t]{2}{*}{ Sampling period } & \multirow[t]{2}{*}{ Sampling site } & \multirow[t]{2}{*}{ S9 fraction ${ }^{a}$} & \multirow[t]{2}{*}{ Control $^{\mathrm{b}}$} & \multicolumn{3}{|c|}{$\begin{array}{l}\text { Dichloromethane extract ( } \mathrm{ml} \text { river } \\
\text { water equivalent/plate) }\end{array}$} & \multicolumn{3}{|c|}{$\begin{array}{l}\text { XAD-2 extract ( } \mathrm{ml} \text { river water } \\
\text { equivalent/plate) }\end{array}$} \\
\hline & & & & 16 & 48 & 143 & 16 & 48 & 143 \\
\hline & & - & $19 \pm 2$ & & & & & & \\
\hline & & + & $27 \pm 3$ & & & & & & \\
\hline \multirow[t]{8}{*}{ July 1999} & 7 & - & & $20(1.0)$ & $17(0.9)$ & $26(1.4)$ & $25(1.3)$ & $23(1.2)$ & $26(1.4)$ \\
\hline & & + & & $35(1.4)$ & $29(1.2)$ & $40(1.6)$ & $25(0.9)$ & $30(1.1)$ & $44(1.6)$ \\
\hline & 8 & - & & $24(1.2)$ & $26(1.3)$ & $51(2.7)$ & $16(0.8)$ & $20(1.0)$ & $23(1.2)$ \\
\hline & & + & & $39(1.3)$ & $79(2.9)$ & $184(6.8)$ & $44(1.6)$ & $79(2.9)$ & $195(7.2)$ \\
\hline & 9 & - & & $23(1.2)$ & $16(0.9)$ & $51(2.6)$ & & & \\
\hline & & + & & $27(1.3)$ & $60(2.2)$ & $155(5.7)$ & & & \\
\hline & & - & $19 \pm 4$ & & & & & & \\
\hline & & + & $30 \pm 3$ & & & & & & \\
\hline \multirow[t]{8}{*}{ Aug 1999} & 7 & - & & $18(1.0)$ & $16(0.8)$ & $19(1.0)$ & $22(1.2)$ & $17(0.9)$ & $22(1.2)$ \\
\hline & & + & & $33(1.1)$ & $23(0.8)$ & $33(1.1)$ & $28(0.9)$ & $29(1.0)$ & $43(1.4)$ \\
\hline & 8 & - & & $24(1.3)$ & $49(2.6)$ & $113(5.9)$ & $25(1.3)$ & $48(2.5)$ & $109(5.7)$ \\
\hline & & + & & $69(2.3)$ & $180(6.0)$ & $437(14.6)$ & $85(2.8)$ & $212(7.1)$ & $827(27.6)$ \\
\hline & 9 & - & & $21(1.1)$ & $20(1.1)$ & $17(0.9)$ & & & \\
\hline & & + & & $28(0.9)$ & $43(1.4)$ & 48 (1.6) & & & \\
\hline & & - & $19 \pm 2$ & & & & & & \\
\hline & & + & $30 \pm 2$ & & & & & & \\
\hline \multirow[t]{6}{*}{ Oct 1999} & 7 & - & & $19(1.0)$ & $24(1.3)$ & $30(1.6)$ & $19(1.0)$ & $22(1.2)$ & $33(1.7)$ \\
\hline & & + & & $30(1.0)$ & $51(1.7)$ & $77(2.8)$ & $34(1.1)$ & $43(1.4)$ & $68(2.3)$ \\
\hline & 8 & - & & $46(2.4)$ & $70(3.7)$ & $247(13.0)$ & $19(1.0)$ & $34(1.8)$ & $68(3.6)$ \\
\hline & & + & & $119(4.0)$ & $283(9.4)$ & $757(25.2)$ & $83(2.8)$ & $184(6.1)$ & $566(18.9)$ \\
\hline & 9 & - & & $21(1.1)$ & $29(1.5)$ & 49 (2.6) & & & \\
\hline & & + & & $42(1.4)$ & $78(2.6)$ & $168(5.6)$ & & & \\
\hline
\end{tabular}

Number in parentheses indicate mutagenic index which is defined as the ratio of the revertants induced in the presence of samples over spontaneous revertants in the negative control.

${ }^{\text {a }}$, In the absence of $\mathrm{S} 9 ;+$, in the presence of $\mathrm{S} 9$

${ }^{\mathrm{b}}$ Mean \pm standard deviation from six replicates

Fig. 3 Mean Comet tail length $(\mu \mathrm{m})$ of human lymphocytes exposed to different doses of river water. Bars denote standard errors. $* P<0.05, * * P<0.01$ represent significant differences compared with the mean tail length of the negative control

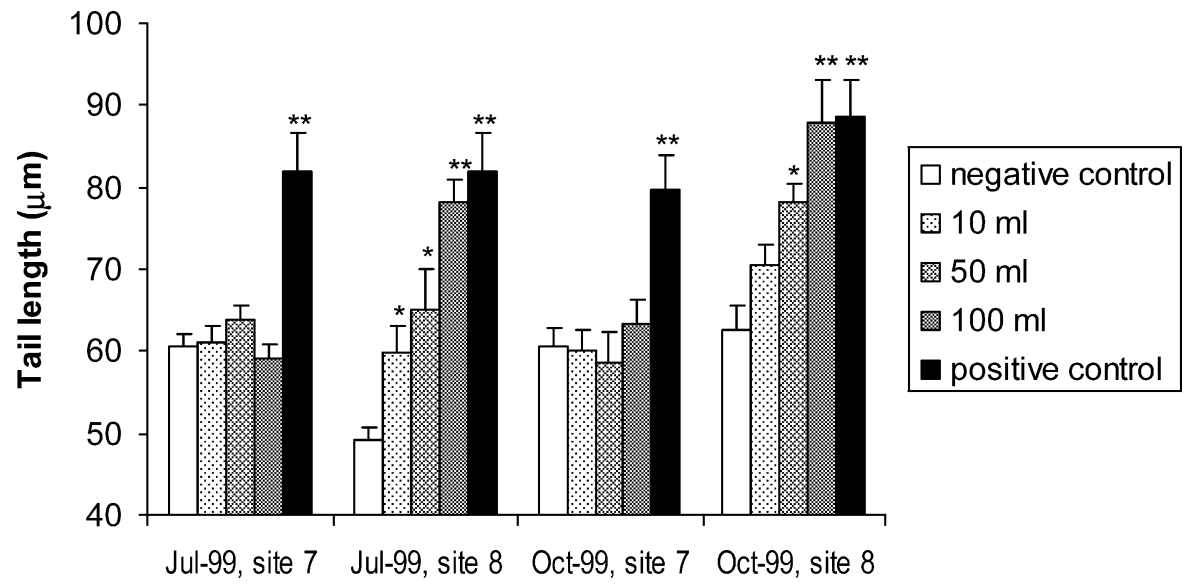


to the sampling site 9 in this study was around 3.0 when 1.51 of sample water used (Lee et al. 1994). The average mutagenic index values calculated in this study were approximately 15 and 4 in $143 \mathrm{ml}$ sample volume at site 8 and 9 respectively. These values are corresponding approximately to 2,000 and 450 revertants per 11 of river water. As we chose the sampling spot at the site 8 as near as possible to prove the source of mutagenicity in river water, the river water did not seem to be completely mixed with the effluent completely at site 8 . Additional dilution and natural removal process, such as sorption to particulate matters, might have reduced the mutagenicity of river water at site 9 from the source. However, we found that the mutagenic potential is about one order of magnitude higher value than reported in the previous study (Lee et al. 1994). The differences in results between the previous study and the present study might be due to different sampling season. Lee et al. (1994) also found that methanol fraction of the XAD-2 adsorbate showed highest mutagenicity, among the hexane, dichloromethane, and methanol fractions, in the river water from the Nakdong River. It is in a good agreement with the characteristics of mutagenic fractions from the Kumho River in this study. It suggests that the type of the mutagens might not have been changed since 1992. As was seen in Table 2, the mutagenic activity with TA98 strain depends on sampling extraction methods, even though mutagens in the Kumho River are thought to be mid-polar organic compounds. Furthermore, mean tail length in the Comet assay (Fig. 3) showed consistent dose-dependent DNA damage, indicating that the chemicals in the river water not only act as frame-shift mutagens but also break human lymphocytes DNA strain.

Mutagenicity in river water was reported in the various places of the world by dye industrial effluents (Maruoka and Yamanaka 1982; Maruoka et al. 1986; Lee et al. 1991; Grover et al. 1996; Kummrow et al. 2003; Umbuzeiro et al. 2004, 2005). Few identification efforts have been successful, although a group of Japanese scientists found novel phenylbenzotriazole (PBTA)-type mutagens (Nukaya et al. 1997, 2001; Oguri et al. 1998; Shiozawa et al. 2000; Watanabe et al. 2001, 2002) and non-chlorinated phenylbenzotriazole (non-ClPBTA)-type compounds (Watanabe et al., 2006) in river water and Brazilian scientists discovered that a few commercial dyes are responsible for the mutagenicity of the Cristais River (Umbuzeiro et al. 2005) recently. We cannot exclude the possibility that the mutagenic activity in the Kumho River is caused by PBTA-type mutagens or commercial azo-dyes, comparing the polarity of the mutagenic fractions in this study with those of identified environmental mutagens. The chemical identification of the mutagen(s) is required for taking reduction measures at the site in the near future.

\section{References}

Aleem, A., \& Malik, A. (2005). Genotoxicity of the Yamura River water at Okhla (Delhi), India. Ecotoxicology and Environmental Safety, 61, 404-412.

Grover, I. S., Kaur, A., \& Mahajan, R. K. (1996). Mutagenicity of some dye effluents. National Academy of Science Letters, 19, 149-158.

Junk, G. A. (1987). Synthetic polymers for accumulating organic compounds from water. In M. Malaiyandi, \& I. H. Suffet (Eds.) Concentration techniques for the collection and analysis of organic chemicals for biological testing of environmental samples (pp. 201-246). Washington DC: American Chemical Society.

Kummrow, F., Rech, C. M., Coimbrão, C. A., Roubicek, D. A., \& Umbuzeiro, G. A. (2003). Comparison of the mutagenic activity of XAD4 and blue rayon extracts of surface water and related drinking water samples. Mutation Research, $541,103-113$.

Kusamran, W. R., Wakabayashi, K., Oguri, A., Tepsuwan, A., Nagao, M., \& Sugimura, T. (1994). Mutagenicities of Bangkok and Tokyo river waters. Mutation Research, 325, 99-104.

LeBel, G. L., Williams, D. T., \& Benoit, F. M. (1987). Use of large-volume resin catridges for the determination of organic contaminants in drinking water derived from the great lakes. In M. Malaiyandi, \& I. H. Suffet (Eds.) Concentration techniques for the collection and analysis of organic chemicals for biological testing of environmental samples (pp. 309-325). Washington DC: American Chemical Society.

Lee, S., \& Kim, J. (1997). The study of mutagenicity and organic pollutant in Nakdong River water basin. Journal of Korean Society of Environmental Engineers, 19, 785-798 (in Korean with English abstract).

Lee, C., Park, Y., Lee, S., Chung, Y., \& Utsumi, H. (1994). Mutagenic evaluation in the middle area of Nakdong River basin. Journal of Korean Society of Environmental Engineers, 16, 415-422 (in Korean with English abstract).

Lee, S.-K., Shim, J.-S., Kim, Y.-H., \& Roh, J.-K. (1991). Ecotoxicological and mutagenicity evaluation of industrial effluents with aquatic organisms (Oryzias latipes, Daphnia magna, Selenastrum capricornutum) and Ames' test with 
Salmonella. Journal of Korean Society of Water Quality, 7, 100-109 (in Korean with English abstract).

Maron, D. M., \& Ames, B. N. (1983). Revised methods for Salmonella mutagenicity test. Mutation Research, 113, 173-215.

Maruoka, S., \& Yamanaka, S. (1982). Mutagenicity in Salmonella typhimurium tester strains of XAD-2-ether extract, recovered from Katsura River water in Kyoto City, and its fractions. Mutation Research, 102, 13-26.

Maruoka, S., Yamanaka, S., \& Yakamoto, Y. (1986). Isolation of mutagenic components by high-performance liquid chromatography from XAD extract of water from the Nishitakase River, Kyoto City, Japan. Science of the Total Environment, 57, 29-38.

Nakamuro, K., Ueno, H., \& Sayato, Y. (1992). Evaluation of mutagenicity of municipal river water concentrated using XAD resin column method. Water Science and Technology, 25, 293-299.

Nukaya, H., Shiozawa, T., Tada, A., Terao, Y., Ohe, T., \& Watanabe, T., et al. (2001). Identification of 2-[2-(acetylamino)-4-amino-5-methoxyphenyl]-5-amino-7-bromo-4chloro- $2 \mathrm{H}$-benzotriazole (PBTA-4) as a potent mutagen in river water in Kyoto and Aichi prefectures, Japan. Mutation Research, 492, 73-80.

Nukaya, H., Yamashita, J., Tsuji, K., Terao, Y., Ohe, T., \& Sawanishi, H., et al. (1997). Isolation and chemicalstructural determination of a novel aromatic amine mutagen in water from the Nishitakase River in Kyoto. Chemical Research in Toxicology, 10, 1060-1066.

Oguri, A., Shiozawa, T., Terao, Y., Nukaya, H., Yamashita, J., \& Ohe, T., et al. (1998). Identification of a 2-phenylbenzotriazole (PBTA)-type mutagen, PBTA-2, in water from the Nishitakase River in Kyoto. Chemical Research in Toxicology, 11, 1195-1200.

Ohe, T., Watanabe, T., \& Wakabayashi, K. (2004). Mutagens in surface waters: a review. Mutation Research, 567, 109-149.

Otsu, R., Horikawa, K., \& Min, B. Y. (1998). Mutagenicity of river water in Korea. Bulletin of Environmental Contamination and Toxicology, 60, 615-619.

Park, Y., Lee, C., Lee, S., Ha, K., Kim, S., \& Chung, Y., et al. (1997). Application of Ames Salmonella test to Nakdong river in Korea. Mizu Kankyo Gakkaishi, 20, 763-767 (in Japanese with English abstract).

Pelon, W., Whitman, B. F., \& Beasley, T. W. (1977). Reversion of histidine-dependent mutant strain of Salmonella Typhimu- rium by Mississippi River water samples. Environmental Science and Technology, 11, 619-623.

Shiozawa, T., Tada, A., Nukaya, H., Watanabe, T., Takahashi, Y., \& Asanoma, M., et al. (2000). Isolation and identification of a new 2-phenylbenzotriazole-type mutagen (PBTA-3) in the Nikko River in Aichi, Japan. Chemical Research in Toxicology, 13, 535-540.

Singh, N. P., McCoy, M. T., Tice, R. R., \& Schneider, E. L. (1988). A simple technique for quantitation of low levels of DNA damage in individual cells. Experimental Cell Research, 175, 184-191.

Umbuzeiro, G. A., Freeman, H. S., Warren, S. H., de Oliveira, D. P., Terao, Y., \& Watanabe, T., et al. (2005). The contribution of azo dyes to the mutagenic activity of the Cristais River. Chemosphere, 60, 55-64.

Umbuzeiro, G. A., Roubicek, D. A., Rech, C. A., Sato, M. I. Z., \& Claxton, L. D. (2004). Investigating the sources of the mutagenic activity found in a river using the Salmonella assay and different water extraction procedures. Chemosphere, 54, 1589-1597.

Van Hoof, F., \& Verheyden, J. (1981). Mutagenic activity in the river Meuse in Belgium. Science of the Total Environment, 20, 15-22.

Vargas, V. M. F., Motta, V. E. P., \& Henriques, J. A. P. (1993). Mutagenic activity detected by the Ames test in river water under the influence of petrochemical industries. Mutation Research, 319, 31-45.

Watanabe, T., Nukaya, H., Terao, Y., Takahashi, Y., Tada, A., \& Takamura, T., et al. (2001). Synthesis of 2-phenylbenzotriazole-type mutagens, PBTA-5 and PBTA-6, and their detection in river water from Japan. Mutation Research, 498, 107-115.

Watanabe, T., Ohba, H., Asanoma, M., Hasei, T., Takamura, T., $\&$ Terao, Y., et al. (2006). Isolation and identification of non-chlorinated phenylbenzotriazole (non-ClPBTA)-type mutagens in the Ho River in Shizuoka Prefecture, Japan. Mutation Research, 609, 13-145.

Watanabe, T., Shiozawa, T., Takahashi, Y., Takahashi, T., Terao, Y., \& Nukaya, H., et al. (2002). Mutagenicity of two 2-phenylbenzotriazole derivatives, 2-[2-(acetylamino)-4(diethylamino)-5-methoxyphenyl]-5-amino-7-bromo-4chloro-2H-benzotriazole and 2-[2-(acetylamino)-4-(dia1lylamino)-5-methoxyphenyl]-5-amino-7-bromo-4chloro- $2 H$-benzotriazole and their detection in river water in Japan. Mutagenesis, 17, 293-299. 